J. Czerwik-Marcinkowska, W. Pusz, and P. Zagożdżon. Cyanobacteria and algae in an old mine adit (Marcinków, Sudety Mountains, southwestern Poland). Journal of Cave and Karst Studies, v. 79, no. 2, p. 122-130. DOI: 10.4311/2016MB0116

\title{
CYANOBACTERIA AND ALGAE IN AN OLD MINE ADIT (MARCINKÓW, SUDETY MOUNTAINS, SOUTHWESTERN POLAND)
}

\author{
Joanna Czerwik-Marcinkowska1, c, Wojciech Pusz ${ }^{2}$, and Paweł Zagożdżon ${ }^{3}$
}

\begin{abstract}
In the interior of an old mine adit in Marcinków, southwestern Poland, during spring, 35 species of phototrophic microorganisms were found on the graphite schists in a corridor $110 \mathrm{~m}$ from the entrance to the adit. There were no visible life forms, but wall patches that were brownish, yellowish, grayish, or reddish surrounded by colorless mucilaginous sheaths were found. Cyanobacteria and algae were only observed in the lab cultures after three months of incubation. We identified 22 species of cyanobacteria, 12 species of green algae, and 1 xanthophyte. Extremely low species diversity of phototrophs in the old mine adit is caused by no light, high humidity, and chemical, substrate composition.
\end{abstract}

\section{Introduction}

Mine adits and caves are natural laboratories to study the mineralogy and biology of the subsurface (Spear et al., 2007), and they are considered an extreme environment for autotrophs and heterotrophs that need light for photosynthesis (Ivarsson-Norbäck et al., 2013). Moreover, Wynn-Williams (2000) stated that extremely harsh environmental conditions for photosynthetic organisms, such as drastic temperature changes, severe water deficit, and low intensity of the photon flux, act as a powerful limiting and selective factor. According to Hernández-Mariné and Canals (1994), Ducarme et al. (2004), Poulíčková and Hašler (2007), and Lamprinou et al. (2009, 2012), caves and adits have a special microclimate and ecological conditions, determined usually by three factors: light, humidity, and temperature. Microorganisms influence mineral deposition by bioprecipitation, biomineralization, and alteration of the rock substrate (Spear et al., 2007). Abandoned mines offer a variety of subterranean microclimates similar to those in natural caves (Tuttle and Taylor, 1994) and provide suitable conditions for the growth of algae, cyanobacteria, and other microorganisms.

Mine reclamation achieves, after a long time, a level similar to the cave environment (Sheffield et al., 1992), but Ňancucheo and Johnson (2012) suggest that mining of metals and coal can adversely affect the environment. Among the most widely documented are the mine-impacted water bodies, characteristically acidic (sometimes extremely) and containing elevated concentrations of iron, other metals, and sulfates. All these constitute an extreme environment that is hostile to most life forms (Johnson, 2009). In most mine adits and caves, indigenous organisms are exclusively microbial and predominantly prokaryotic, whereas eukaryotic microorganisms include acidophilic and acid tolerant species of microalgae, fungi, yeasts, protozoa, and rotifers (Baker et al., 2004; Das et al., 2009; Chlebicki et al., 2014).

The biodiversity of acidophilic and acid tolerant algae is relatively limited (Novis and Harding, 2007). Microalgae reported to be actively accumulating metals in highly acidic environments include some Chlorophyta (Chlamydomonas acidophila, Dunaliella acidophila, Klebsormidium acidophilum), Heterokontophyta (Ochromonas sp.), and Euglenophyta (Euglena mutabilis). Subaerial cyanobacteria and algae are photoautotrophic and photoheterotrophic microorganisms occurring in various natural habitats, as well as in environments changed by human activities and mining (Shtina et al., 1985).

Development of aerophytic algae in caves and adits depends, among other things, on $\mathrm{pH}$ of water, available water type (seeping or standing), and substratum (Martinčič et al., 1981; Chang and Chang-Schneider, 1991). In our study, water is one of the essential factors for the aerophytic algae and cyanobacteria colonization and growth. Generally, the presence of running or seeping water accelerates growth of aerophytic algae in caves and adits. Strong ecological differentiation of particular species in their relation to liquid water and to mineral composition of substratum is relevant (Peksa and Škaloud, 2011). Aerophytic algae can survive in the environmental only when humidity is high enough (Mulec and Kosi, 2009).

Microorganisms in caves were quite intensively studied in many countries in Europe and around the world (e.g., Pattanaik et al., 2007; Smith and Olson, 2007; Martínez and Asencio, 2010; Czerwik-Marcinkowska and Mrozińska, 2011; Vinogradowa et al., 2011; Czerwik-Marcinkowska et al., 2015). However, data on photoautotrophs inhabiting graphite schists in mine adits are very scarce (Ňancucheo and Johnson, 2012). According to our study, the old mine adit in Marcinków is an especially unfavorable environment for the existence of microorganisms, mainly due to absence of light, hence our study was aimed to determine the diversity of subaerial cyanobacteria and algae, and the influence of the main environmental variables on their development.

\footnotetext{
${ }^{1}$ Department of Botany, Institute of Biology, Jan Kochanowski University, Świętokrzyska 15, PL-25-406 Kielce, Poland

${ }^{2}$ Division of Plant Pathology and Mycology, Department of Plant Protection, Wrocław University of Environmental and Life Sciences, Poland

${ }^{3}$ Division of Applied Geology, Dewatering and Ecology, Wrocław University of Technology, Poland

c Corresponding Author: marcinko@kielce.com.pl
} 


\section{Materials and Methods}

\section{Adit Description}

Marcinków is a small settlement known since Middle Ages as a center of mining activity (Stysz and Mączka, 2009; Zagożdżon and Zagożdżon, 2009), currently almost completely depopulated. It is located about $9 \mathrm{~km}$ east of Bystrzyca Kłodzka, on the western slopes of the socalled Krowiarki hills, close to Śnieżnik massif in the Sudety Mountains. The mining operations from the fifteenth century to the beginning of seventeenth century were concentrated on the exploitation of lead ores containing silver. Intensive exploration works and exploitation of $\mathrm{Pb}$, $\mathrm{Ag}$, and $\mathrm{Cu}$ were carried out in the eighteenth century. After World War II (1948-1965), exploitation of uranium ores and searches for graphite deposits were conducted here (see Don, 1988; Madziarz and Sztuk, 2004; Stysz and Mączka, 2009). In Marcinków, there are remnants of seven adits of different ages and states of preservation (Stysz and Mączka, 2009). The examined adit (called adit number 2, 3, 4, or 5 or Middle Uranium Adit in various sources) is located on the geographical coordinates $50^{\circ} 17^{\prime} 1.7^{\prime \prime} \mathrm{N}$ and $16^{\circ} 46^{\prime} 53^{\prime \prime} \mathrm{E}$; its entry is situated slightly above the valley bottom. This old mine adit was used for uranium mining in 1950 (Stysz and Mączka, 2009). Its length is about $180 \mathrm{~m}$, average height $2 \mathrm{~m}$, and width varies between 1.7 and $2.2 \mathrm{~m}$. Graphite and mica schists with garnets and opaque minerals (magnetite, pyrite), occur in the adit, also dripstone with ferruginous sinters (straws, stalactites, draperies). The corridors are dark and only penetrated by low-intensity light at the entrance, but at the sampling site there was no detectable light. Humidity is high (almost $90 \%$ ) due to the more or less regular supply of water from crevices.

\section{Sampling}

The old mine adit was sampled 25 May 2015. One surface sample was taken from a $1 \mathrm{~m}^{2}$ area of wall (Fig. 1). Four samples (S1, S2, S3, S4) were taken $110 \mathrm{~m}$ from the adit entrance. They consisted of biofilms brownish, yellowish, grayish, or reddish surrounded by colorless mucilaginous sheaths (Fig. 2). About 2 to 3 grams of each sample were scraped from walls using a scalpel, placed into labeled sterile plastic bags, and transported the next day to the lab not on ice. In the lab, material from each sample was examined under a light microscope (Jenamed 2) and aseptically placed into Petri dishes with fresh agarized (1\%) nutrient Bold's Basal Medium (Bischoff and

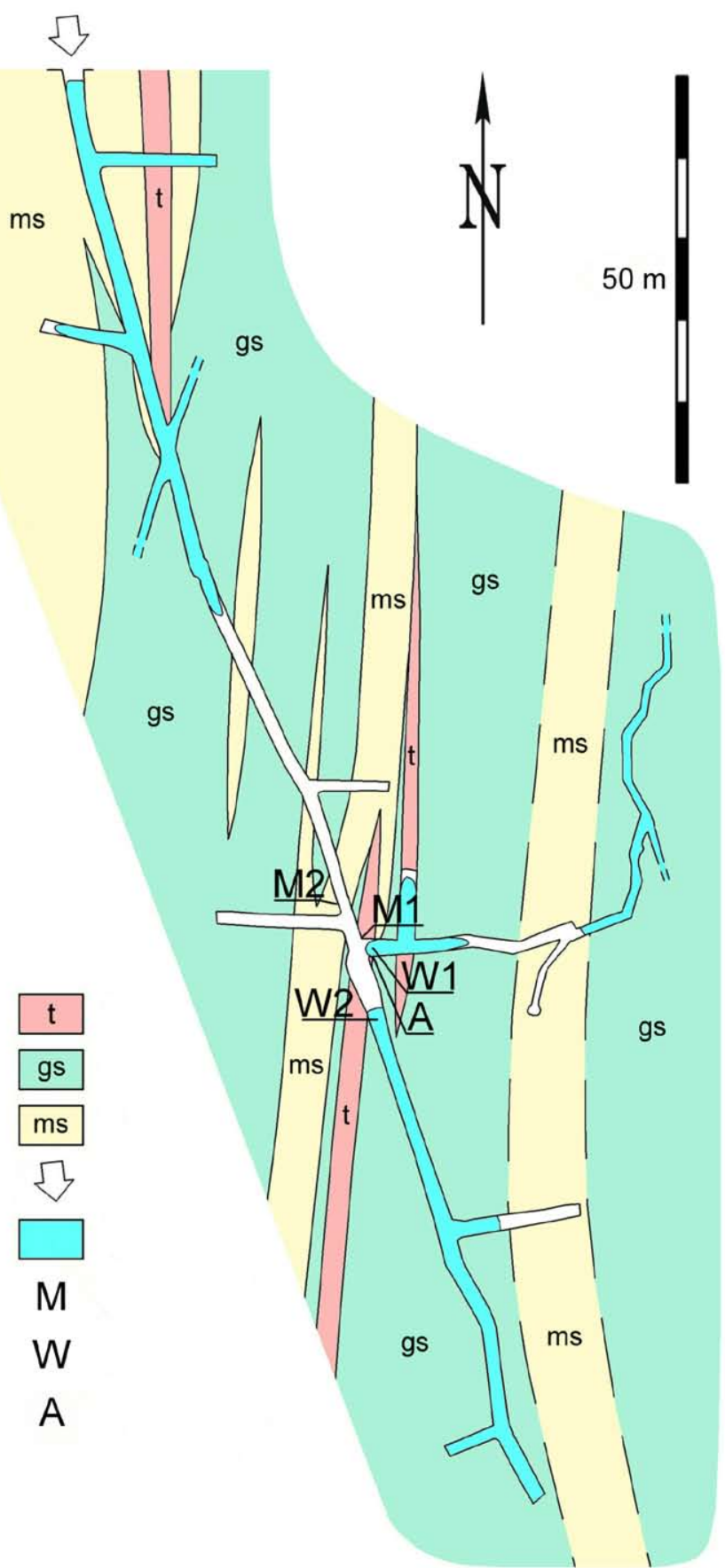

Figure 1. Locations of microorganisms (A, detail in Fig. 2), mineral substratum and water sampling sites in old mine adit in Marcinków. (t) tectonic zones; (gs) graphite schists; (ms) mica schists; (arrow) entrance of adit; zones of stagnant water marked with blue color; (M1, M2) mineral substratum sampling sites; (W1, W2) water sampling sites.

Bold, 1963) and cultured at $20^{\circ} \mathrm{C}$ in a 12-h light/12-h dark cycle at $3000 \mu \mathrm{Em}^{-2} \mathrm{~s}^{-1} \mathrm{Ix}$ provided by $40 \mathrm{~W}$ cool fluorescent tubes. A microscopic study of cultures began from the first appearance of cyanobacterial and algal growth during three months of cultivation. The gradual development of microorganism was observed. All species were identified in living states using a light microscope. The cells for transmission electron microscopy were processed according to Massalski et al. (1995), and photomicrographs were taken with a TESLA BS 600. The following taxonomic treatises were used: Anagnostidis and Komárek (1988), Komárek and Anagnostidis (2005), Ettl and Gärtner (1995). Ecological characteristic of cyanobacteria and algae are according to John et al. (2011), and Whitton (2012).

The description of the substratum is based on two analyses of chemical composition of rock and iron sinters beside 


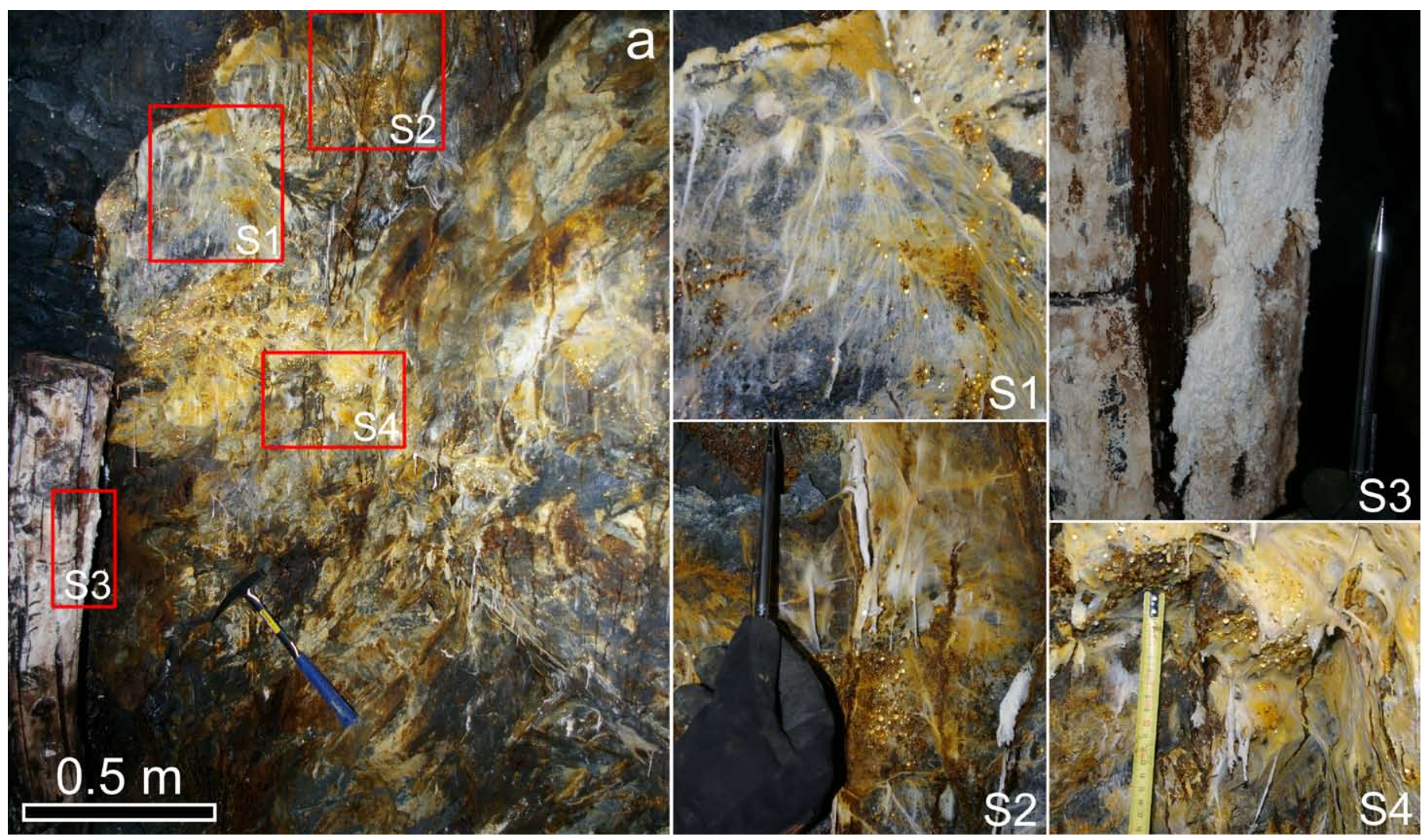

Figure 2. Algological sampling sites (S1, S2, S3, S4) in old mine adit in Marcinków, colored patches of microorganisms on cell wall: (a) map shows location of sampling sites in cartographic scale; (S1-S4) photos present enlarged details of four sites. All biological samples were collected from the $1 \mathrm{~m}^{2}$ area.

the microorganisms sampling site (A in Fig. 1)). The analyses were carried out using XRF, GFAAS, and ICP - MS methods, and gravimetric analysis to determine the LOI value. Sample M1 was taken from a wall located $110 \mathrm{~m}$ in from the entrance (Fig. 1 - M1). Sample M2, to determine the chemical composition of iron sinters, covering large parts of walls and roof, was taken from several points located about 190-210 m in from the entrance of adit (Fig. 1 - M2). The analyses were done with ICP - OES and IC methods (anions), spectrophotometric method (nitrites), FIA (sulfides), and potentiometric method $(\mathrm{pH})$.

\section{Data Analysis}

The species occurrence was determined on a scale of 0 to 1 , and for the data collected on four studied sites were subjected to statistical analysis (Hammer et al., 2001). With the PAST program, frequency of species and diversity of samples were calculated and significances of differences between these parameters were determined. The KruskalWallis test for species frequency and the diversity $t$ test for species diversity were performed. Correspondence analysis was done to determine variations in data on species occurrence. Detrended correspondence analysis for the data set of species ecological characteristic was carried out. Canonical-variate analysis (CVA) for three taxonomic groups to identify and isolate ecological characteristics of each group was performed. The Monte Carlo permutation test was done to determine significance of diversity in the species data collection. All the above analyses were carried out using the software package Canoco 5.0 (Ter Braak and Šmilauer, 2012).

\section{Results}

In total, 22 species of cyanobacteria, 12 species of green algae, and one xanthophyte were documented (Table 1). On the wall in the old mine adit, it was observed that microorganisms were arranged in patches that were brownish, yellowish, or grayish in color and surrounded by colorless mucilaginous sheaths. Seventeen species of coccoid and five filamentous cyanobacteria were found. The genus Gloeocapsa was the most frequently occurring (four species), followed by Cyanosaccus, Leptolyngbya (three species each), then by Aphanothece, Chroococcus, and Pleurocapsa (two species each). The Gloeocapsa species found here indicate that growth of these taxa on the graphite schist walls were the most optimal. Cyanobacteria from Chroococcales, Synechococcales, Nostocales, and Pleurocapsales groups were found (Figs. 3, 4). Among the Chlorococcales order, Aphanocapsa, Aphanothece, Asterocapsa, Chroococcus, Cyanosaccus, and Gloeocapsa were present. In studied samples, 12 green algae species were found, among which 
Table 1. Locations of subaerial cyanobacteria and algae at old mine adit in Marcinków. Numbers show sampling sites. Information regarding ecology are from the authors own observations (color sheath/cell) and from the literature: John et al. (2011) and Whitton (2012).

\begin{tabular}{|c|c|c|c|}
\hline Taxa & Sampling Site & Color Sheath/Cell & Ecology \\
\hline \multicolumn{4}{|l|}{ Cyanobacteria } \\
\hline Aphanocapsa muscicola & $1,2,3$ & brownish or greyish & terrestrial \\
\hline Aphanothece saxicola & 2,4 & reddish or yellowish-brownish & on wet rocks \\
\hline Aphanothece sp. & 3 & greyish & terrestrial \\
\hline Asterocapsa sp. & 4 & brownish & terrestrial \\
\hline Chroococcus spelaeus & 1,2 & yellowish-brownish & terrestrial \\
\hline Chroococcus sp. & 2 & yellowish & terrestrial \\
\hline Cyanosaccus aegeus & 3,4 & yellowish or yellowish-brownish & terrestrial \\
\hline Cyanosaccus sp. & 1,2 & yellowish & terrestrial \\
\hline Cyanosaccus atticus & 2 & greyish, bluish & euendolithic, carbonate substrates \\
\hline Gloeocapsa biformis & 3,4 & orangish or yellowish-brownish & chasmoendolithic \\
\hline Gleocapsa nigrescens & 3 & greyish & epilithic \\
\hline Gloeocapsa novacekii & 2,4 & yellowish or yellowish-brownish & epilithic \\
\hline Gloeocapsa rupicola & $1,2,3$ & reddish & epilithic \\
\hline Gloeothece palea & 2,4 & pale yellowish or yellow-brownish & on wet rocks \\
\hline Hassalia sp. & 1 & bluish-greyish & terrestrial \\
\hline Leptolyngbya carnea & 1,2 & yellowish-brownish & terrestrial \\
\hline Leptolyngbya sp. & 3 & yellowish-greyish & terrestrial \\
\hline Leptolyngbya sp. & 1,4 & brownish-greyish & terrestrial \\
\hline Pleurocapsa minor & 4 & yellowish-brownish & on rocks among other algae \\
\hline Pleurocapsa sp. & 4 & yellowish & on wet rocks \\
\hline Scytonema mirabile & 3 & yellow-brownish & on moist soil \\
\hline Scytonema sp. & 2,3 & bluish-greyish & on moist soil \\
\hline \multicolumn{4}{|l|}{ Chlorophyta } \\
\hline Chlorella miniata & 2,3 & greenish-bluish & subaerial \\
\hline Chlorella vulgaris & 3 & greenish & subaerial \\
\hline Chlorella sp. & 4 & greenish-bluish & subaerial \\
\hline Chlorococcum humicolum & 4 & greyish & neutral to acid soils, porous acidic rocks \\
\hline Gloeocystis vesiculosa & 3,4 & greenish-brownish & terrestrial \\
\hline Gloeocystis sp. & 2,3 & greyish & terrestrial \\
\hline Kirchneriella sp. & 2,3 & yellowish & on wet rocks \\
\hline Stichococcus bacillaris & $1,2,3,4$ & yellowish-rownish & $\begin{array}{l}\text { bright patches on soil, stone walls, and other damp } \\
\text { surfaces }\end{array}$ \\
\hline Stichococcus minor & 3,4 & yellowish-greenish & terrestrial \\
\hline Stichococcus sp. & $1,2,3,4$ & greenish-greyish & terrestrial \\
\hline Stichococcus sp. & 1,4 & greenish & terrestrial \\
\hline Pseudococcomyxa simplex & 2,3 & yellowish-blackish & on wet soil \\
\hline \multicolumn{4}{|l|}{ Heterokonthophyta/Xanthophyceae } \\
\hline Xanthonema exile & 2,4 & yellowish-blackish & chasmoendolithic \\
\hline
\end{tabular}

the most frequently encountered were members of the genera Stichococcus (4 species), followed by Chlorella (3 species) and Gloeocystis (2 species). Whereas green algae species, such as: Chlorococcum humicolum, Kirchneriella sp., and Pseudococcomyxa simplex were found only once. A chasmoendolithic (organisms growing in rocks fissures) yellow-green algae (Xanthophytes), namely Xanthonema exile, was only found at two sites.

Species frequency in the sampling sites was on average 0.5 ; only in the $S 1$ site were the species less numerous (0.25). These differences were not statistically significant. Similar properties also involved the Shannon diversity index for the studied samples, but the test showed significant differences due to the low diversity of the first site (Fig. 5). As evidenced by the analysis of species distribution in the correspondence-analysis ordination space, the gradient differentiating the occurrence of species along the first axis can be interpreted as an increasing light gradient (Fig. 6). Phototrophs species: Asterocapsa sp., Chlorella sp., Chlorococcum humicolum, Pleurocapsa minor, Pleurocapsa sp., group in the right part of the ordination diagram, whereas the microorganisms, in the left part, indicate a reduction 
in demand for light, even at photon flux densities lower than the photosynthetic compensation point. Detrended correspondence analysis was also done on the basis of the studied samples ecological properties (Fig. 7). The species from wet rocks and soils were distributed along the first ordination axis, whereas on the second ordination axis were most of the remaining species. All the studied species were placed into three taxonomic groups. The environmental data was correlated with taxonomical affiliation. The canonical-variate analysis result distinctly indicates the dissimilarity of the adaptation features among the three groups (Fig. 8).

The adit rock represents an altered (weathered) mica schist, strongly crushed during tectonic movements. A high content of $\mathrm{SiO}_{2}(57.20 \%)$ and $\mathrm{Al}_{2} \mathrm{O}_{3}(16.33 \%)$ is typical for a silicate rock. Other significant components are oxides of $\mathrm{Fe}\left(\mathrm{Fe}_{2} \mathrm{O}_{3}: 8.10 \%\right)$ and of $\mathrm{Mg}(3.17 \%)$ and $\mathrm{K}$ (about $3.73 \%$ ). The most important trace elements are $\mathrm{Ba}$ (382 ppm), Rb, $\mathrm{V}, \mathrm{Zr}$, and $\mathrm{Cr}$ (about 135 to $170 \mathrm{ppm}$ each). The only main element of iron sinters was iron oxide $\left(\mathrm{Fe}_{2} \mathrm{O}_{3}\right)$, representing $65.30 \%$ of a sample $M 2$, except silica $(1.92 \%)$, all other components occurring in amounts from 0.32 to less than $0.01 \%$. The sample showed a very high value of loss on ignition of $32.79 \%$. The most common trace elements are Mo (144 ppm), Zn (103 ppm), Co (58 ppm) and Cu (50 $\mathrm{ppm})$. There were differences in the chemical composition of mine-water samples collected from sites close to each other and representing various water types. The first sample (W2) was a fresh water with a slightly acidic nature $(\mathrm{pH}=6.4)$, with total hardness of $101 \mathrm{mg} \mathrm{L}^{-1} \mathrm{CaCO}_{3}$

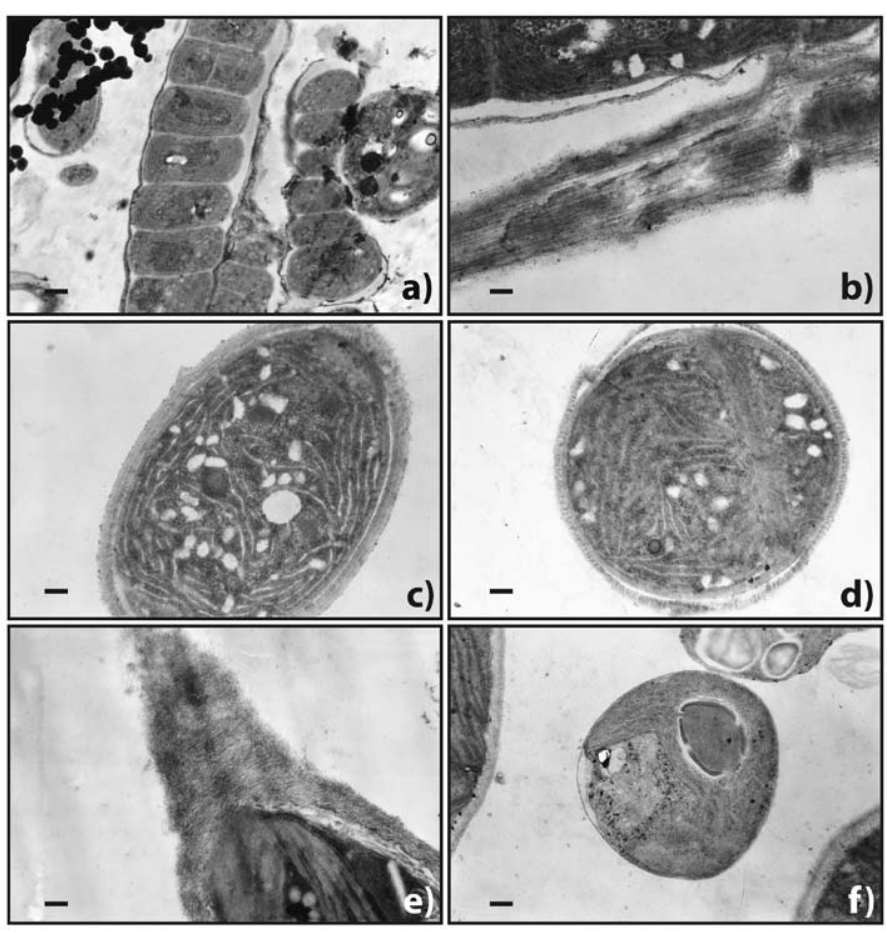

Figure 3. Electron micrographs of an ultrathin section of the biofilm including cyanobacteria and green algae from mine adit in Marcinków (a) Filaments of Leptolyngbya sp. show cells in different developmental stages within the same aggregate. (b) transverse section of cyanobacteria cell-wall layers with bacterium inside the cavity in the cell wall, and the electron dense material. (c-d) Pleurocapsa minor. (e) transverse section of green algae cell wall in mucilage outside the cell wall. (f) cross section of Chlorella vulgaris cell. Scale bar: $5 \mu \mathrm{m}$.

(carbonate hardness: $52.5 \mathrm{mg} \mathrm{L}^{-1} \mathrm{CaCO}_{3}$, and non-carbonate hardness: $48 \mathrm{mg} \mathrm{L}^{-1} \mathrm{CaCO}_{3}$ ) and total mineralization of about $200 \mathrm{mg} \mathrm{L}^{-1}$. A second sample (W1) was stagnant water in a zone of extraction of sulfide ores and had a very low $\mathrm{pH}$ (3.7), hardness at the level of $128 \mathrm{mg} \mathrm{L}^{-1} \mathrm{CaCO}_{3}$ (entirely non-carbonate hardness), and total mineralization about $285 \mathrm{mg} \mathrm{L}^{-1}$.

\section{Discussion}

The majority of cyanobacteria have mechanisms for occurrence under extreme environmental conditions - in deserts, in the Antarctic region, or under and within rocks, as well as in caves (Lukešová, 1993; Flechtner, 1999). They are very resistant to low oxygen levels, very high or very low temperatures, and poor light (Mannan and Pakrasi, 1993). Moreover, cyanobacteria exhibit very strong phenoplasticity, hence a variety of characteristics under pressure of environmental factors. Most cyanobacteria sheaths appeared colored because of pigments present acting as filters to diminish the amount of incident light (Krumbein and Potts, 1978).

In the old mine adit in Marcinków, species belonging to the order Chroococcales were the most abundant cyanobacteria documented at all sampling sites. However, coccoid species were more abundant in darkness than filamentous taxa, but in Vinogradowa et al. (1998), the proportion of coccoid to filamentous forms decreased as irradiance got less. The genus Gloeocapsa, the most commonly encountered cyanobacteria in the adit, has also been recorded in many other caves in Europe: from Poland (Czerwik-Marcinkowska and Mrozińska, 2011), Slovenia (Mulec et al., 2008), and Russia (Mazina and Maximov, 2011), while in Greece (Lamprinou et al., 2009) and Spain (Urzi et al., 2010) the diversity of this species was relatively lower. Chroococcus are also common in caves (Cennamo et al., 2012; CzerwikMarcinkowska, 2013). Species from Scytonema genus are considered to be one of the most dominant aeroterrestrial cyanobacteria (Pattanaik et al., 2007). Colonies of Aphanocapsa muscicola present in the studied mine adit were also found in caves and on dry rocks in Israel (Vinogradova et al., 1998, 2009, 2011). Similarly, Aphanocapsa saxicola occurring in S2 and S4 sites in the studied mine adit was also observed in terrestrial habitats of Israel, such as on dry rocks of north and south facing slopes, in soil samples of terra rossa, in soil crusts on loess, and in sand on shallow slopes (Vinogradova et al., 1995).

It is interesting that in the old mine adit Oscillatoriales were not observed; usually representatives of this group play a significant role in cavernicilous microorganisms. According to Mulec et al. (2008), coccoid forms tolerate low light 

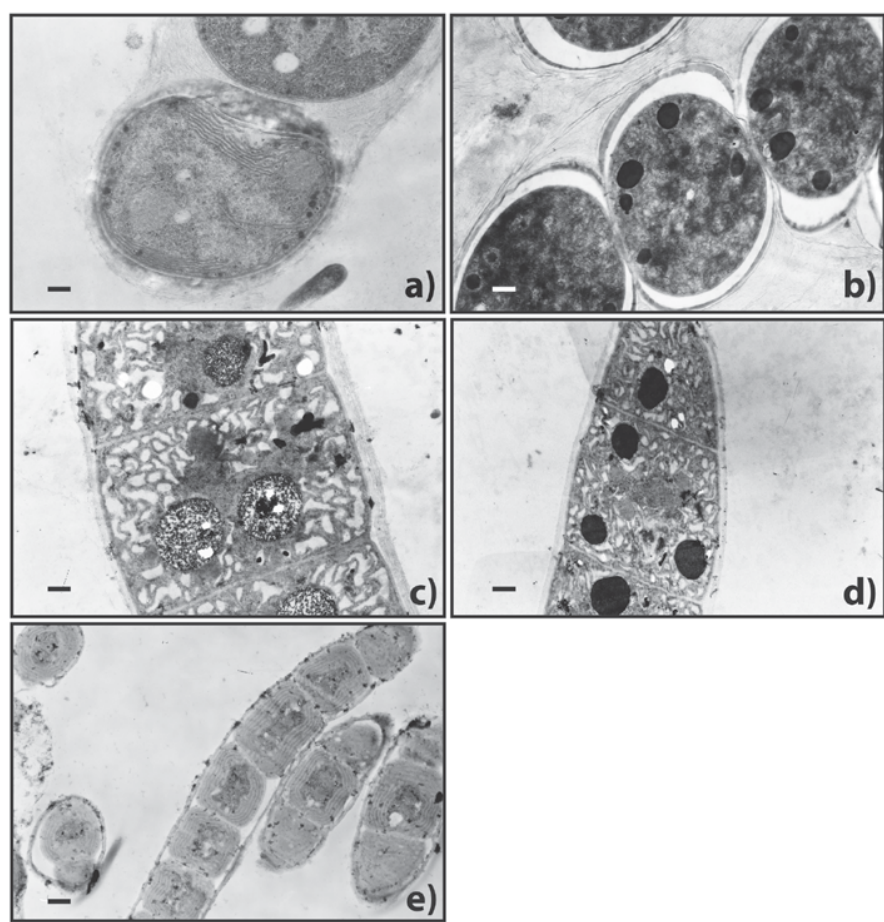

d)

Figure 4. Electron micrographs of cyanobacteria filaments in studied adit (a-b) Leptolyngbya sp. from sampling site S1 (c-d) Scytonema sp.; apex of a filament; from sampling site S2 and S3 (e) Leptolyngbya sp. from sampling site S4. Scale bar: $10 \mu \mathrm{m}$.

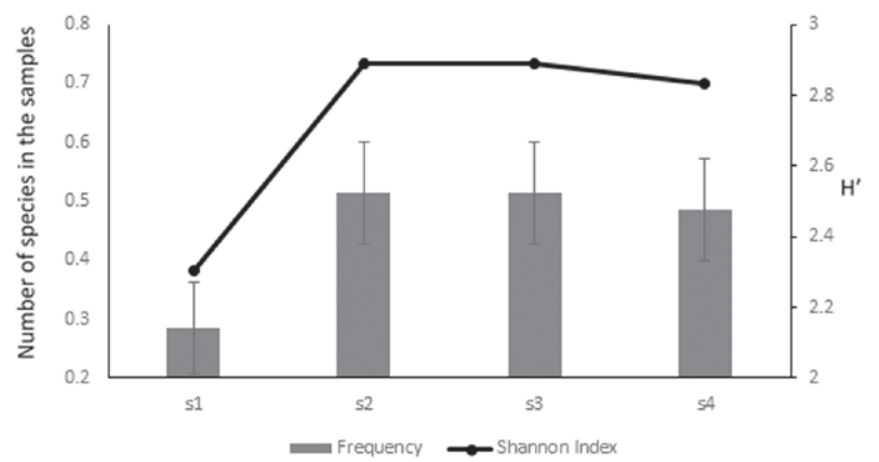

Figure 5. Percentage of total species ( \pm SE, column diagram, left side) and diversity index Shannon-Wiener $\left(\mathrm{H}^{\prime}\right.$, line diagram, right side) in studied samples (S1, S2, S3, S4). The frequency differences between samples are not statistically significant (Kruskal-Wallis test, $\mathrm{p}>0.05$ ) but the $\mathrm{H}^{\prime}$ differences are statistically significant (diversity $t$ tests, $p<0,05)$.

intensity most successfully among cyanobacteria, although their proportion in speleocommunities is very high. Mulec et al. (2008) suggest that the oscillatorians trichomal species adapt better to conditions with constantly low values of light density compared to nostocaceans. Adaptation mechanisms of cyanobacteria allow them to more successful acclimatization to aphotic environments, thus it can be supposed that extremely low diversity of microorganisms in old mine adit is caused by the cumulative effects of stress factors such as no-light, graphite schists substrate, and high humidity. The majority of cyanobacteria species found in the mine adit were recorded in similar environments in Poland (Czerwik-Marcinkowska and Mrozińska, 2011). Green alga Chlorella vulgaris present in the studied adit, occurs besides in caves, on wet soils, tree bark, wet rock surfaces, and walls in the Tyrolean Alps, also on volcanic soil in Japan and Himalayas (Ettl and Gärtner, 1995). Experiments on axenic cultures grown in an inorganic medium carried out by Kol (1966) showed that several algal strains can tolerate the complete absence of light; and furthermore, some algal strains showed intensive development even under such conditions. Many microorganisms from caves and adits have the ability to adapt to the ecological conditions and are aerophytes, terrestrial forms, and the edaphon.

Acid mine drainage is a phenomenon commonly associated with mining activities throughout the world (Novis and 


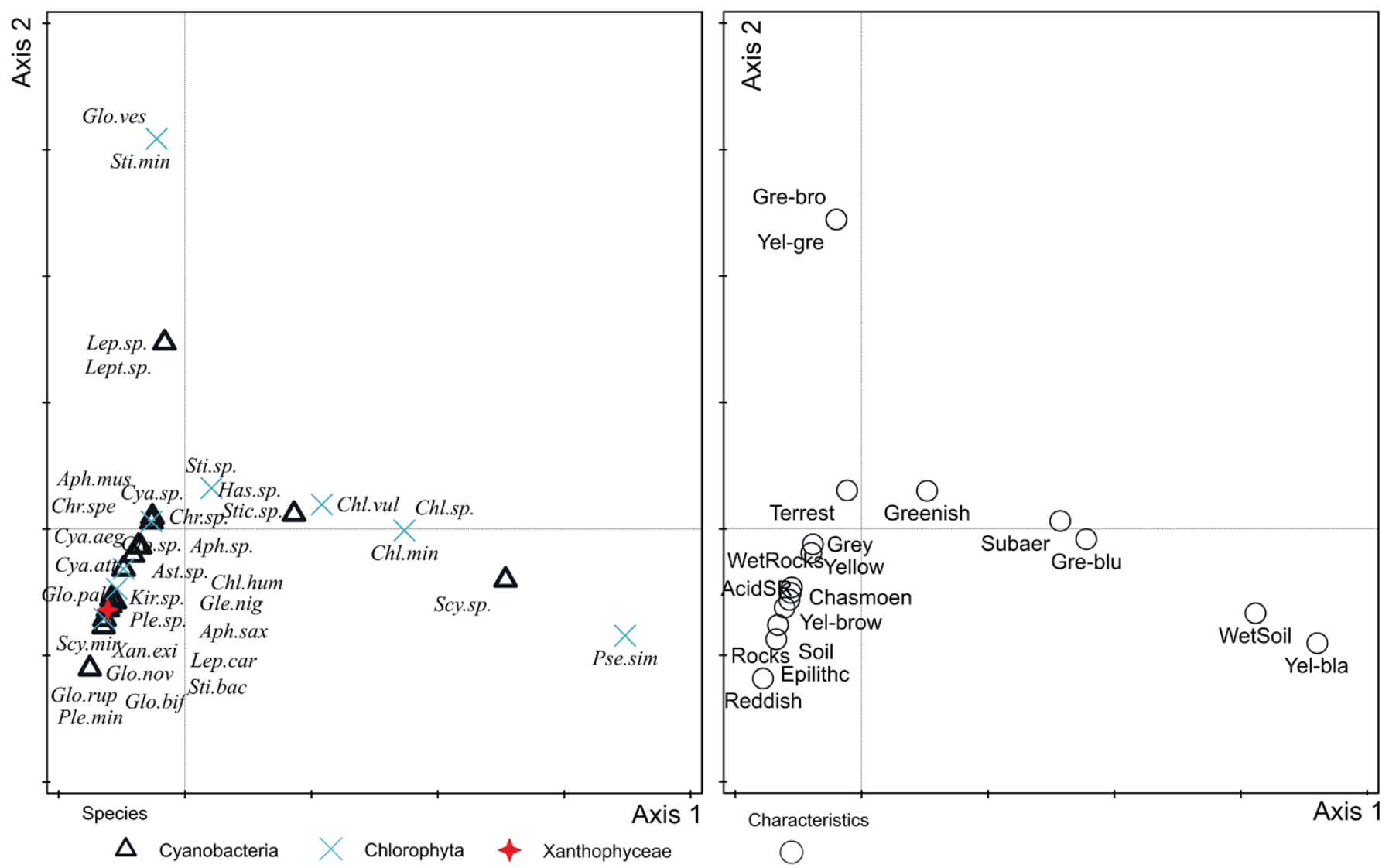

Figure 7. Non-trend analysis of the compatibility (detrended correspondence analysis) of species environments in studied samples. Right diagram - ecological properties of species found in the samples, left diagram - species distribution in terms of these properties. Abbreviations of variables' names: AcidSR (acid soils); Chasmoen (chasmoendolithic); Epilithic (epilithic); Gre-blu (greenish-bluish); Gre-bro (greenish-brownish); Greenish (greenish); Grey (greyish); Reddish (reddish); Rocks (on rocks among other algae); Soil (on moist soil); Subaer (subaerial); Terrest (terrestrial); WetRocks (on wet rocks); WetSoil (on wet soil); Yel-bla (yellowish-blackish); Yel-brow (yellowish-brownish); Yel-gre (yellowish-greyish). Abbreviations of species names are as in Figure 6, and full names are in Table 1.

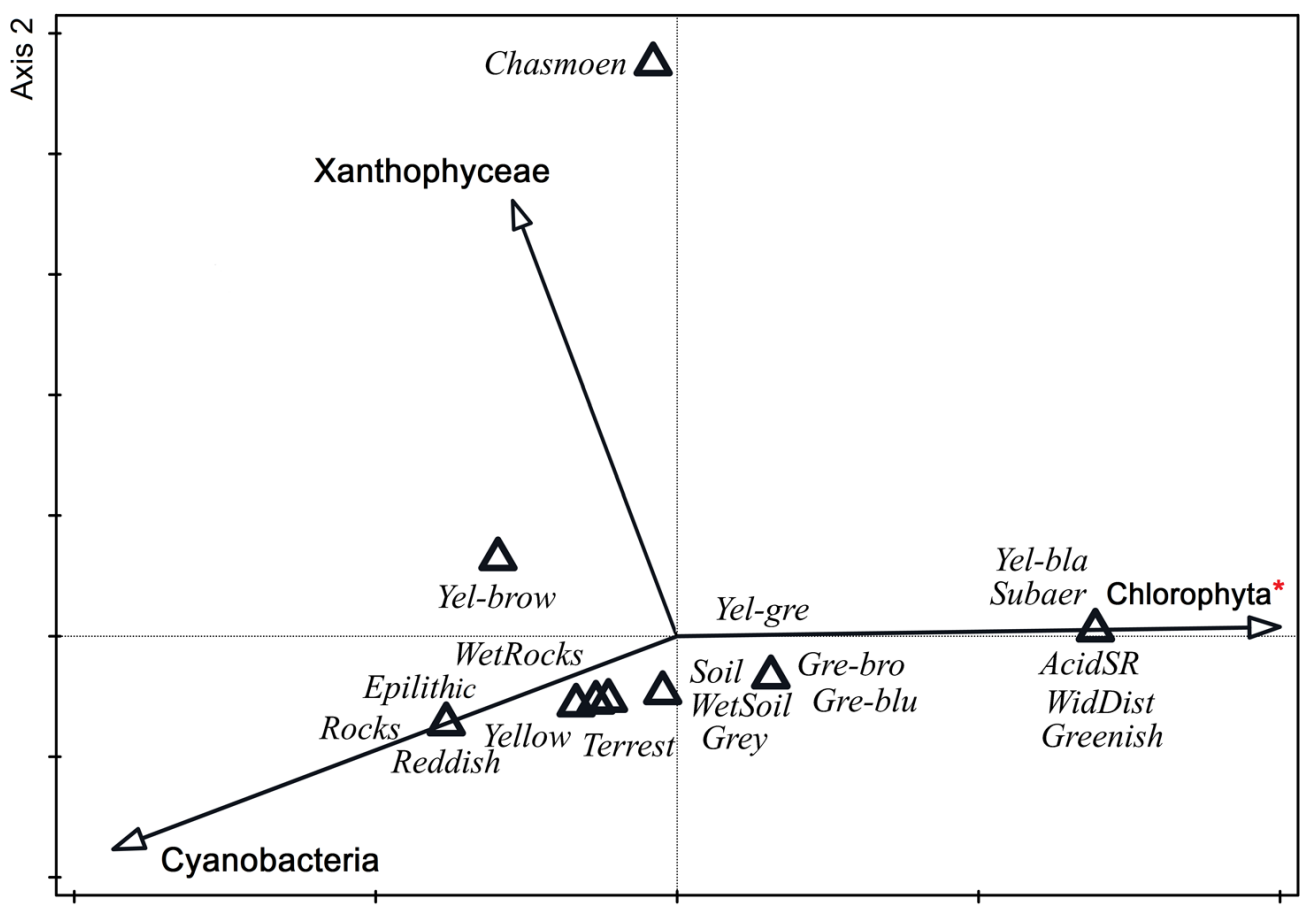

Axis 1
Figure 8. Discriminant analysis (canonical variate analysis) of species environment data in studied samples. The asterisk indicates the variable significant for the data set (Monte Carlo test, $p<0.05$ ). Abbreviations of variables' names: AcidSR (acid soils); Epilithic (epilithic); Grey (greyish); Gre-blu (greenishbluish); Gre-bro (greenish-brownish); Greenish (greenish); Reddish (reddish); Rocks (on rocks); Soil (on moist soil); Subaer (subaerial); Terrest (terrestrial); WetRocks (on wet rocks); WetSoil (on wet soil); WidDist (wide distribution); Yellow (yellowish); Yel-bla (yellowish-blackish); Yel-brow (yellowish-brownish); Yel-gre (yellowish-greyish). 
Harding, 2007). Such acidification is the consequence of sulfides in rock strata becoming exposed to water and oxygen, and extremely acidic habitats in adits are associated with mining spoil (Novis and Harding, 2007). Such drainage began during the industrial revolution and now accounts for most of the extremely acidic habitats worldwide (Johnson, 1998). Light quality and its duration are the most obvious factors influencing cyanobacterial diversity in caves and adits (Whitton, 2012), but many studies (e.g., Chapman, 1993; Lundberg and McFarlane, 2011) dealt with one or the other of two well-defined environments. Water availability in adits and caves is important for growth and colonization, but most caves and adits, at least in Europe, North America, and Australia, are deep and damp and their walls are covered with colored cyanobacteria and green algae (see Vinogradova et al., 1998).

\section{Conclusions}

Although no visible life of cyanobacteria and algae communities in the old mine adit in Marcinków were present, but applying cultivation, we found 35 species of phototrophic microorganisms mostly known as subaerial forms. Extremely low species diversity of algae in the mine adit might be caused by multifactor stress, combining no light, substrate components, and high humidity. This investigation of the diversity of subaerial cyanobacteria and algae in an old mine adit was the first conducted in Poland.

\section{Acknowledgements}

Many thanks to Prof. Andrzej Massalski for invaluable help with electron and light-microscope images and two anonymous reviewers for their comments on the manuscript. Special thanks also to Dr. Anna Wojciechowska for technical assistance. Field works were carried out within the grant of Wrocław University of Technology No. S50037.

\section{References}

Anagnostidis, K., and Komárek, J., 1988, Modern approach to the classification system of Cyanophytes. 3. Oscillatoriales: Archiv für Hydrobiologie, Supplement v. 80 (Algological Studies no. 50-53), p. 327-472.

Baker, B.J., Lutz, M.A., Dawson, S.C., Bond, P.L., and Banfield, J.F., 2004, Metabolically active eukaryotic communities in extremely acidic mine drainage: Applied and Environmental Microbiology, v. 70, no. 10, p. 6264-6271. https://doi.org/10.1128/AEM.70.10.6264-6271.2004.

Bischoff, H.W., and Bold, H.C., 1963, Phycological Studies IV. Some soil algae from Enchanted Rock and related algal species: University of Texas Publications, v. 6318, 95 p.

Cennamo, P., Marzano, Ch., Ciniglia, C., Pinto, G., Cappelletti, P., Caputo, P., and Pollio, A., 2012, A survey of the algal flora of anthropogenic caves of Campi Flegrei (Naples, Italy) archeological district: Journal of Cave and Karst Studies, v. 74, no. 3, p. 243-250. https://doi.org/ 10.4311/2011JCKS0194.

Chang, T.-P., and Chang-Schneider, H., 1991, Algen in vier süddeutschen Höhlen: Berichte der Bayerischen Botanischhen Gesellschaft (Algae in four southern German caves): Reports of the Bavarian Botanical Society), v. 62, p. 221-229.

Chapman, P., 1993, Caves and Cave Life: London, Harper Collins, 219 p.

Chlebicki, A., Zielenkiewicz, U., and Wilczek, A.M., 2014, Fungi are not involved in biofilm formation on rock wall in subterranean arsenic mine in Poland: Nova Hedwigia, v. 99, no. 1-2, p. 255-269. https://doi.org/10.1127/0029-5035/2014/0178.

Czerwik-Marcinkowska, J., 2013, Observations on aerophytic cyanobacteria and algae from ten caves in the Ojców National Park: Acta Agrobotanica, v. 66, no. 1, p. 39-52. https://doi.org/10.5586/aa.2013.005.

Czerwik-Marcinkowska, J., and Mrozińska, T., 2011, Algae and cyanobacteria in caves of the Polish Jura: Polish Botanical Journal, v. 56, no. 2, p. 203-243.

Czerwik-Marcinkowska, J., Wojciechowska, A., and Massalski, A., 2015, Biodiversity of limestone caves: aggregations of aerophytic algae and cyanobacteria in relation to site factors: Polish Journal of Ecology, v. 63, no. 4, p. 481-499. https://doi.org/10.3161/ 15052249PJE2015.63.4.002.

Das, B.K., Roy, A., Koschorreck, M., Mandal, S.M., Wendt-Potthoff, K., and Bhattacharya, J., 2009, Occurrence and role of algae and fungi in acid mine drainage environment with special reference to metals and sulfate immobilization: Water Research, v. 43, no. 4, p. 883-894. https:// doi.org/10.1016/j.waters.2008.11.046.

Don, J., 1988, Geologia strefy złożowej Kletna - Janowej Góry, in Wojciechowska, I., ed., Wybrane zagadnienia geologii i mineralizacji metamorfiku Sìnieznika (Problems of Geology and Mineralization of the Śnieżnik Area): Wydawnictwa Uniwersytetu Wrocławskiego, p. 57-80.

Ducarme, X., André, H.M., Wauthy, G., and Lebrun, P., 2004, Comparison of endogenic and cave communities: Microarthropod density and mite species richness: European Journal of Soil Biology, v. 40, no. 3-4, p. 129-138. https://doi.org/10.1016/j.ejsobi.2004.10.003.

Ettl, H., and Gärtner, G., 1995, Syllabus der Boden-, Luft- und Flechtenalgen: Stuttgart, Jena, New York, Gustav Fischer, 721 p.

Flechtner, V.R., 1999, Enigmatic desert soil algae, in Seckbach, J., ed., Enigmatic Microorganisms and Life in Extreme Environments: Dordrecht, Kluwer Academic Publishers, p. 231-241.

Hammer, Ø., Harper, D.A.T., and Ryan, P.D., 2001, PAST: Paleontological statistics software package for education and data analysis: Paleontologia Elektronica, v. 4, no. 1, p. 1-9.

Hernández-Mariné, M., and Canals, T., 1994, Herpyzonema pulverulentum (Mastigocladaceae), a new cavernicolous atmophytic and lime-incrusted cyanophyte: Algological Studies, v. 75, p. 123-136.

Ivarsson Norbäck, L., Ivarsson, M., Lundberg, J.E.K., Sallstedt, T., and Rydin, C., 2013, Epilithic and aerophilic diatoms in the artificial environment of Kungsträdgården metro station, Stockholm, Sweden: International Journal of Speleology, v. 42, no. 3, p. 289-297. https://doi. org/10.5038/1827-806X.42.3.12.

John, D.M., Whitton, B.A., and Brook, A.J., 2011, The Freshwater Algal Flora of the British Isles: An Identification Guide to Freshwater and Terrestrial Algae: Cambridge, Cambridge University Press, p. 41-896.

Johnson, D.B., 1998, Biodiversity and ecology of acidophilic microorganisms: Microbiology Ecology, v. 27, no. 4, p. 307-317. https://doi. org/10.1111/j.1574-6941.1998.tb00547.x.

Johnson, D.B., 2009, Extremophiles: acid environments, in Schaechter, M., ed., Encyclopedia of Microbiology: Oxford UK, Elsevier, p. $107-126$. 
Kol, E., 1966, Algal growth experiments in the Baradla Cave at Aggtelek (Biospeleologica hungarica XXI): International Journal of Speleology, v. 2, no. 4, p. 457-474. https://doi.org/10.5038/1827-806X.2.4.18.

Komárek, J., and Anagnostidis, K., 2005, Cyanoprokaryota 2. Teil/2nd Part: Oscillatoriales, in Büdel, B., Krienitz, L., Gärdner, G., and Schagerl, M., eds, Süsswasserflora von Mitteleuropa 19/2: Heidelberg, Elsevier, Spektrum, 759 p.

Krumbein, W.E., and Potts, M., 1978, Light penetration, salinity, and other growth regulating factors of four stromatolitic environments along the shores of the Gulf of Aqaba (Sinai), in Friedman, G.M., ed., Abstracts 10th International Congress on Sedimentology, p. 363.

Lamprinou, V., Danielidis, D.B., Economou-Amilli, A., and Pantazidou, A., 2012, Distribution survey of Cyanobacteria in three Greek caves of Peloponnese: International Journal of Speleology, v. 41, no. 2, p. 267-272. https://doi.org/10.5038/1827-806X.41.2.12.

Lamprinou, V., Pantazidou, A., Papadogiannaki, G., Radea, C. and Economou-Amilli, A., 2009, Cyanobacteria and associated invertebrates in Leontari Cave, Attica (Greece): Fottea, v. 9, no. 1, p. 155-164. https://doi.org/10.5507/fot.2009.014.

Lundberg, J., and McFarlane, D.A., 2011, Subaerial freshwater phosphatic stromatolites in Deer Cave, Sarawak - a unique geobiological cave formation: Geomorphology, v. 128, no. 1-2, p. 57-72. https://doi.org/10.1016/j.geomorph.2010.12.022.

Lukešová, A., 1993, Soil algae in four secondary successional stages on abandoned fields: Algological Studies, v. 71, p. 81-102.

Madziarz, M., and Sztuk, H., 2004, Kopalnia w Marcinkowie — zapomniane świadectwo wielusetletniej historii eksploatacji górniczej na Dolnym Śląsku (The mine in Marcinków - the forgotten certificate a few hundred history of mine exploration in the Lower Silesia: Przegląd Górniczy), v. 12 , no. 4 , p. 50-55.

Mannan, R.M., and Pakrasi, H.B., 1993, Dark heterotrophic growth conditions result in an increase in the content of photosystem II units in the filamentous cyanobacterium Anabaena variabilis ATCC 29413: Plant Physiology, v. 103, p. 971-977. https://doi.org/10.1104/pp.103.3.971.

Martinčič, A., Vrhovšek, D., and Batič, F., 1981, Flora v jamah Slovenije z umetno osvetlitvijo (Flora in caves with artificial lights in Slovenia): Biološki Vestnik,v. 29, no. 2, p. 27-56.

Martínez, A., and Asencio, A.D., 2010, Distribution of cyanobacteria at the Gelda Cave (Spain) by physical parameters: Journal of Cave and Karst Studies, v. 72, no. 1, p. 11-20. https://doi.org/10.4311/jcks20091sc0082.

Massalski, A., Mrozińska, T., and Olech, M., 1995, Lobococcus irregularis (Boye-Pet.) Reisigl var. antarcicus var.nov. (Chlorellales, Chlorophyta) from King George Island, South Shetland Islands, Antarctica and its ultrastructure: Nova Hedwigia, v. 61, p. 199-206.

Mazina, S.E., and Maximov, V.N., 2011, Photosynthetic organism communities of the Akhshtyrskaya Excursion Cave: Moscow University Biological Sciences Bulletin, v. 66, no. 1, p. 37-41. https://doi.org/10.3103/S009639251101007X.

Mulec, J., Kosi G., and Vrhovšek, D., 2008, Characterization of cave aerophytic algal communities and effects of irradiance levels on production of pigment: Journal of Cave and Karst Studies, v. 70, no. 1, p. 3-12.

Mulec, J., and Kosi, G., 2009, Lampenflora algae and methods of growth control: Journal of Cave and Karst Studies, v. 71, no. 2, p. 109-115.

Ňancucheo, I., and Johnson, D.B., 2012, Acidophilic algae isolated from mine-impacted environments and their roles in sustaining heterotrophic acidophiles: Frontiers in Microbiology, v. 3, p. 320-325. https://doi.org/10.3389/fmicb.2012.00325.

Novis, P.M., and Harding, J.S., 2007, Extreme acidophiles: freshwater algae associated with acid mine drainage, in Seckbach, J., ed., Algae and Cyanobacteria in Extreme Environments: Springer, Heidelberg, p. 443-463.

Pattanaik, B., Schumann, R., and Karsten, U., 2007, Effects of ultraviolet radiation on Cyanobacteria and their protective mechanisms, in Seckbach, J., ed., Algae and Cyanobacteria in Extreme Environments: Springer, Heidelberg, p. 29-45.

Peksa, O., and Škaloud, P., 2011, Do photobionts influence the ecology of lichens? A case study of environmental preferences in symbiotic green alga Asterochloris (Trebouxiophyceae): Molecular Ecology, v. 20, no. 18, p.3936-3948. https://doi.org/10.1111/j.1365- 294X.2011.05168.x.

Poulíčkova, A., and Hašler, P., 2007, Aerophytic diatoms from caves in central Moravia (Czech Republic): Preslia, v. 79, p. $185-204$.

Sheffield, S.R., Shaw, J.H., Heidt, G.A., and McClenaghan, L.R., 1992, Guidelines for the protection of bat roosts: Journal of Mammalogy, v. 73 , no. 3, p. 707-710.

Shtina, E.A., Neganova, L.B., Yel'shina, T.A., Shilova, I., and Andonova, M.F., 1985, Soil algae in polluted soils: Soviet Soil Science, v. 17, p. $18-27$.

Smith T., and Olson R., 2007, A taxonomic survey of lamp flora (Algae and Cyanobacteria) in electrically lit passages within Mammoth Cave National Park, Kentucky: International Journal of Speleology, v. 36, no. 2, p. 105-114. https://doi.org/10.5038/1827-806X.36.2.6.

Spear, J.R., Barton, H.A., Robertson, C.E., Francis, C.A., and Pace, N.R., 2007, Microbial community biofabrics in a geothermal mine adit: Applied and Environmental Microbiology, v. 73, no. 19, p. 6172-6180. https://doi.org/10.1128/AEM.00393-07.

Stysz, M., and Mączka, M., 2009, Dzieje goìrnictwa w Marcinkowie. Inwentaryzacja pozostałosìci roboìt goìrniczych dawnych kopalnì rud polimetalicznych (The history of mining in Marcinków. The inventory of remains of ore mines), in Zagożdżon, P.P., and Maziarz, M., eds., Dzieje Górnictwa - Element Europejskiego Dziedzictwa Kultury: Oficyna Wydawnicza Politechniki Wrocławskiej, v. 2, p. $297-310$.

Ter Braak, C.J.F, and Šmilauer, P., 2012, Canoco Reference Manual and User's Guide: Software for Ordination (version 5.0): Ithaca, Microcomputer Power, $496 \mathrm{p}$.

Tuttle, M.D., and Taylor, D.A.R., 1994, Bats and Mines: Bat Conservation International Resource Publication, no. 3, 50 p.

Urzi, C., de Leo, F., Bruno, L., and Albertano, P., 2010, Microbial diversity in Paleolithic caves: a study case on the phototrophic biofilms of the Cave of Bats (Zuheros, Spain): Microbial Ecology, v. 60, p. 116-129. https://doi.org/10.1007/s00248-010-9710-x.

Vinogradova, O., Darienko, T., Pavliček, T., and Nevo, E., 2011, Cyanoprokaryotes and algae of Arubota'im salt cave (Mount Sedom, Dead Sea area, Israel): Nova Hedwigia, v. 93, no. 1-2, p. 107-124. https://doi.org/10.1127/0029-5035/2011/0093-0107.

Vinogradova, O.N., Wasser, S.P., and Nevo, E., 2009, Algae of the Sefunim Cave (Israel): species, diversity affected by light, humidity and rock stresses: International Journal on Algae, v. 11, no. 2, p. 99-116. https://doi.org/10.1615/InterJAlgae.v11.i2.10.

Vinogradova, O.N., Kovalenko, O.V., Wasser, S., Nevo, E., Tsarenko, P.M., Stupina, V.V., and Kondratiuk, E.S., 1995, Algae of the Mount Carmel National Park (Israel): Algologia, v. 5, no. 2, p. 178-192.

Vinogradova, O.N., Kovalenko, O.V., Wasser, S.P., Nevo, E., and Weinstein-Evron, M., 1998, Species diversity gradient to darkness stress in blue-green algae/cyanobacteria: a microscale test in a prehistoric cave, Mount Carmel, Israel: Israel Journal of Plant Sciences, v. 46, no. 3, p. 229-238. https://doi.org/10.1080/07929978.1998.10676732.

Whitton, B.A., ed., 2012, Ecology of Cyanobacteria II. Their Diversity in Space and Time: Springer Science+Business Media B.V., 706 p. https:// doi.org/10.1007/978-94-007-3855-3.

Wynn-Williams, D.D., 2000, Cyanobacteria in deserts-life at the limit? in Whitton, B.A., and Potts, M., eds., Ecology of Cyanobacteria II: Their Diversity in Time and Space: Kluwer Academic Dordrecht, p. 341-366. https://doi.org/10.1007/0-306-46855-7_13.

Zagożdżon, K.D., and Zagożdżon, P., 2009, Dawne i wspoiłczesne procesy geologiczne w sztolni nr 3 w Marcinkowie (Old and contemporary geological processes in adit N03 in Marcinków), in Zagożdżon, P.P., and Madziarz, M., eds., Dzieje Górnictwa - Element Europejskiego Dziedzictwa Kultury: Oficyna Wydawnicza Politechniki Wrocławskiej, v. 2, p. 357-367. 